\title{
Metabolic Rate and Body Size Relationships in Adult and Growing Homeotherms
}

\author{
Piotr POCZOPKO
}

Poczopko P., 1979: Metabolic rate and body size relationships in adult and growing homeotherms. Acta theriol., 24, 12: 125-136 [With 3 Tables \& 3 Figs.].

In adult homeotherms the basal metabolic rate (BMR) changes proportionally with approximately 0.75 power of the body weight so it is possible to accept the $\mathrm{kg}^{0.75}$ as metabolic unit of the body size. When the data on the BMR of adult homeotherms are expressed per this unit one can distinguish several metabolic levels characteristic for different groups of homeotherms. In growing homeotherms the relationship between the $B M R$ and body weight even on a log. log. plot is not represented by a straight line. For this reason discussed relationship cannot be characterised by a single regression coefficient. It is concluded, therefore, that the analysis of intraspecific relation between $B M R$ and body size with the help of equation $M=a W^{b}$ should be discarded as not giving clear and easily comparable results. In comparative studies the metabolic rate of growing homeotherms can be expressed per common metabolic unit of the body size i.e. $\mathrm{kg} 0.75$ because this approach enables to compare the metabolic rates, both intra- and interspecifically.

[Inst. Animal Physiology \& Nutrition, Pol. Acad. Sci., 05-110 Jabłonna near Warsaw, Poland]

\section{INTRODUCTION}

$\mathrm{R} \mathrm{ubner} \mathrm{(1883)} \mathrm{formulated} \mathrm{the} \mathrm{so} \mathrm{called} \mathrm{surface} \mathrm{rule,} \mathrm{which} \mathrm{states}$ that fasting homeotherm produces daily $1000 \mathrm{kcal}$ of heat per square meter of body surface, on the basis of energy metabolism determinations in dogs of different size. Later_on, however, scientists (e.g., V o it, 1901) were less concerned with intraspecific but primarily with interspecific comparisons of the metabolic rates in adult homeotherms of different size. Since the end of 19th century the relationship between body size and the metabolic rate of adult animals became more clear but the intraspecific relations between these variables still remains obscure. This paper has been written with the hope that it may contribute to clarification of this problem.

\section{INTERSPECIFIC RELATIONS BETWEEN BODY SIZE AND METABOLIC RATE}

Since the rate of heat production in the same animal may vary within broad limits a rigorous standarization of conditions under which meas- 
urements are carried out is needed, in order to enable valid comparisons of the metabolic rates in different animals. It is usual to compare the so called basal $(B M R)$ or standard (SMR) metabolic rates which are measured when an animal is at complete rest, in the postapsorbtive state and in a thermoneutral environment.

As the reference standard of metabolic rate $\mathrm{Rubner}$ (1883) and many of his scientific successors used a square meter of the surface area. Because of difficulty in measuring animal surface area, different formulas for its estimation have been developed. Well known, and still used, is the formula proposes by $\mathrm{M}$ e e $\mathrm{h}$ (1879)

$$
S=k W^{2 / s}
$$

where $S=$ surface area in $\mathrm{dm}^{2}, W=$ body weight in $\mathrm{kg}$ and $k=$ an empirically established constant for particular groups of animals. But owing to the difficulty in measuring animal surface area, established $k$ values usually are encumbered with considerable error, amounting to as much as 20 to 50 percent (Kle iber, 1947, 1961, 1965, P oc zopko, 1965, 1971). $\mathrm{K} \mathrm{rogh}$ (1916) suggested, therefore, the adoption of a value 10 as an approximation of the empirically derived $k$. However, the analysis of the relation between body size and $B M R$ based on a power equation proved to be more convenient. When the logarithms of body weight are plotted against logarithms of the $B M R$ then the relationship between these variables is represented by a straight line. This means that $B M R$ must be proportional to a given power of the body weight, since if

$$
\log M=\log a+b \log W \text {, then } M=a W b \text {, }
$$

where: $M=B M R, W=$ weight of an animal in $\mathrm{kg}$, whereas $a$ and $b$ are constants.

\section{Table 1}

The exponents $b$ in the equation $M=a W^{b}$, in interspecific relation between $B M R$

\begin{tabular}{|c|c|c|c|}
\hline Animals & $\begin{array}{l}\text { Range of body } \\
\text { weights }\end{array}$ & $b$ & Authors \\
\hline Mammals +3 sp. birds & $150 \mathrm{~g}-$ & 0.739 & Kleiber, 1932 \\
\hline Mammals & $21 \mathrm{~g}-600 \mathrm{~kg}$ & 0.756 & Kleiber, 1947 \\
\hline Mammals & $20 \mathrm{~g}-1000 \mathrm{~kg}$ & 0.734 & Brody \& Procter, 1932 \\
\hline Birds & $10 \mathrm{~g}-100 \mathrm{~kg}$ & $0.64^{*}$ & Brody \& Procter, 1932 \\
\hline Birds & $0.1-10 \mathrm{~kg}$ & 0.744 & King \& Farner, 1961 \\
\hline Birds, passerine & $6.1-866 \mathrm{~g}$ & 0.724 & $\begin{array}{l}\text { Lasiewski \& Dawson, } \\
1967\end{array}$ \\
\hline Birds, nonpasserine & $3 \mathrm{~g}-100 \mathrm{~kg}$ & 0.723 & $\begin{array}{l}\text { Lasiewski \& Dawson, } \\
1967\end{array}$ \\
\hline $\begin{array}{l}\text { Marsupials } \\
\text { Different poikilotherms }\end{array}$ & $\begin{array}{l}14 \mathrm{~g}-32.5 \mathrm{~kg} \\
\text { from microorga- } \\
\text { nisms to } 10 \mathrm{~kg}\end{array}$ & $\begin{array}{l}0.74 \\
0.75\end{array}$ & $\begin{array}{l}\text { Dawson \& Hulbert, } 1970 \\
\text { Hemmingsen, } 1960\end{array}$ \\
\hline
\end{tabular}
and body size.

All $b$ values except that marked * are statistically indistinguishable from each other. 
Table 1 shows that when interspecific comparisons of the metabolic rates are concerned the exponents $b$ are remarkably similar in spite of being calculated by different authors using data obtained on quite different groups of animals. Indeed, the exponents listed in the mentioned table in all but one case are statistically indistinguishable from each other, and now the exponent suggested by $\mathrm{K}$ l e i b e r $(1947,1961)$ i.e. ${ }^{3 / 4}$ or 0.75 is commonly accepted. Thus the weight of an animal in $\mathrm{kg}$ raised to 0.75 power makes a good reference standard, usually called the metabolic unit of the body size or simply metabolic body size. When the metabolic rate of different animals are to be compared one can simply divide their daily heat production by the metabolic unit of the body size. The quotient thus obtained is called by Kle iber (1961) the metabolic level.

$\mathrm{K}$ l e i b e r $(1947,1961)$ on the basis of results on $B M R$ in 36 groups of mammals (but only 12 species, sic!) obtained at different laboratories

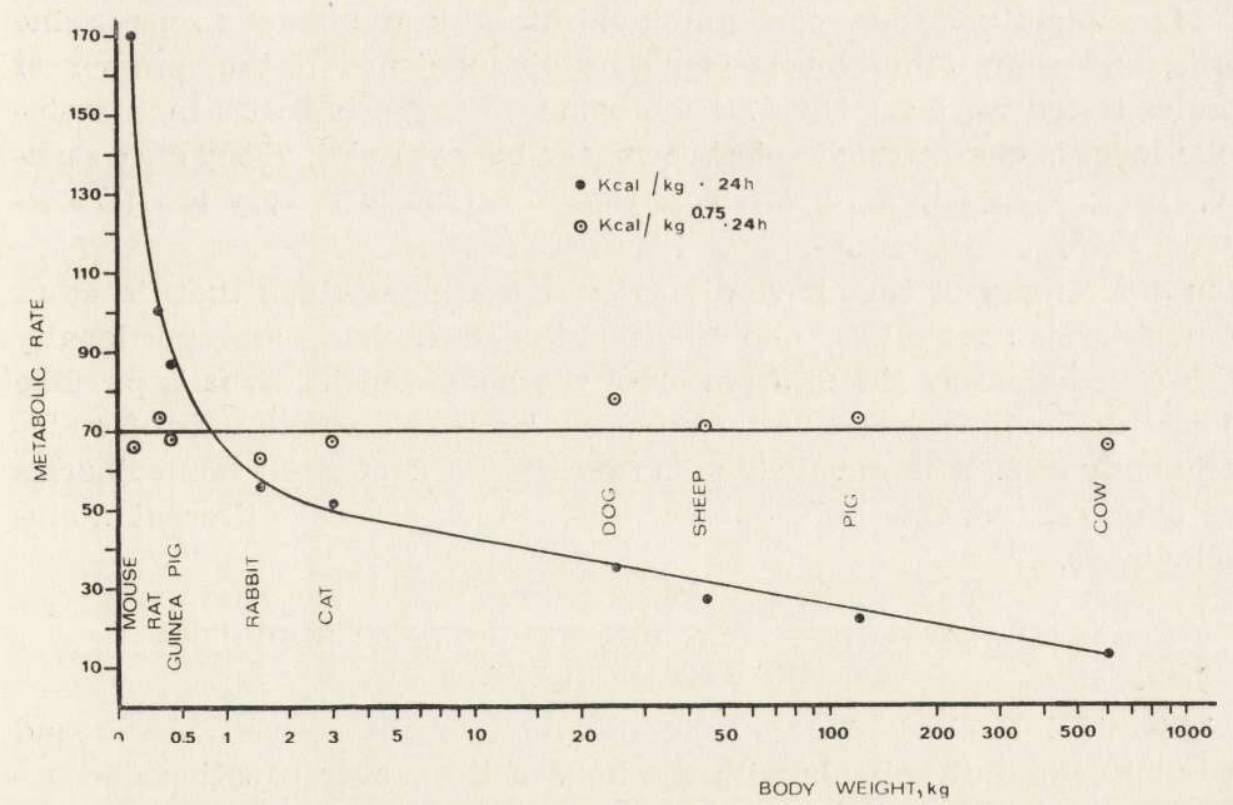

Fig. 1. Relationship between $B M R$ and body size in adult mammals expressed per kilogram of the body weight (curve) and per metabolic unit of the body size (kg0.75). Data on BMR from Kleiber, 1961.

concluded that the mean metabolic level for mammals is $70 \mathrm{kcal} / \mathrm{kg}^{0.75}$. $24 \mathrm{~h}$. The data on which Kleiber based his conclusion are presented in Fig. 1 in which a curve represents the metabolic rate expressed per $\mathrm{kg}$ of the body weight, whereas a straight, horizontal line represents the same rates expressed per $\mathrm{kg}^{0.75}$. 
Kleiber's interspecific mean represents a convenient base line enabling one to decide whether the metabolic rate of a particular animal, or group of animals, is high or low.

Increasing amounts of data on BMR in adult homeotherms led some authors to conclude that some metabolic levels different than that suggested by Kleiber can be distinguished (L a s i e w s k i \& D a w s o n. 1967; Dawson \& H ulbert, 1970). Poczopko (1971) after analysing a large body of published evidence concluded that at least four distinctly different metabolic levels exist in adult homeotherms, which expressed per $\mathrm{kg}^{0.75}$ and per 24 hours are:

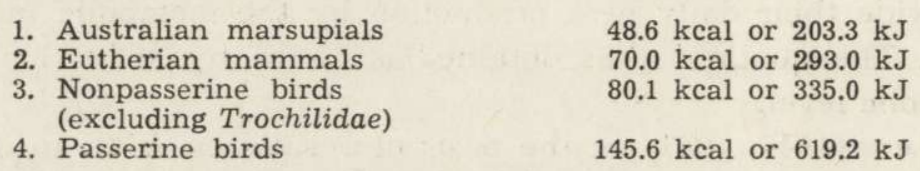

He suspected also that the metabolic level of bats conforms with that of Marsupials and that of hummingbirds with the level in passerine birds, and some other levels could be distinguished if the number of species tested were sufficient. Some evidence suggests that a high metabolic level is characteristic of shrews (G ę b c z y ński, 1965; P o c z o pk o, 1971; V o g e l, 1976), whereas that of Edentata is very low (D a ws o $n, 1973)$.

In a summary of the above discussion one can conclude that: in adult homeotherms (as well as poikilotherms) the $B M R$ changes proportionally with approximately the 0.75 power of the body weight, so it is possible to accept, for the sake of uniformity, the $\mathrm{kg}^{0.75}$ as a single unit of metabolic body size. When available data on the BMR of adult homeotherms are expressed as this unit, one can distinguish several different metabolic levels.

\section{INTRASPECIFIC RELATIONSHIP BETWEEN BODY SIZE AND METABOLIC RATE}

A fruitful method of analysing the relationship between $B M R$ and body size in adult animals with the help of the power equation encouraged many authors to analyse in a similar fashion the intraspecific relationship between these variables. However, the results obtained were definitely less satisfactory. Table 2 shows that the values of exponent $b$ in equation (2) calculated by different authors vary considerably even for the same species. This is particularly evident in case of cattle and rat. So the exponent $b$, which in case of interspecific comparison can really by accepted as constant in the case of intraspecific analysis cannot be treated as such. Moreover, H art (1971) as well as Bla xt e r (1972) stated that the $b$ values compiled by them concerned adult 
(but still growing, sic!) animals. Also the average weights of animals given in the table by $\mathrm{Th}$ onney et al. (1976) suggest that the same concerns their data on $b$ values. The question is, therefore, to what extent can we use the exponents compiled in Table 2 i.e. over what

Table 2

The exponent $b$ in intraspecific power equation $M=a W b$.

\begin{tabular}{|c|c|c|c|c|}
\hline Species & $\begin{array}{c}\text { Range of } \\
\text { body weights }\end{array}$ & $\begin{array}{l}\text { No. of } \\
\text { values }\end{array}$ & $\begin{array}{c}\text { Range of } \\
\text { values }\end{array}$ & Reference \\
\hline Mouse & $5-40 \mathrm{~g}$ & 1 & 0.92 & 1 \\
\hline Mouse & mature & 1 & 0.75 & 2 \\
\hline Clethrionomys glareolus & $15-30$ & 5 & $0.64-0.75$ & 1 \\
\hline Peromyscus m. nebrascensis & $15-23$ & 1 & 0.43 & 1 \\
\hline P. m. austerus & $14-23$ & 1 & 0.54 & 1 \\
\hline P. m. sonoriensis & $17-25$ & 1 & 0.25 & 1 \\
\hline P. m. artemisiae & $18-30$ & 1 & 0.94 & 1 \\
\hline P. m. areas & $22-37$ & 1 & 0.76 & 1 \\
\hline P. sitkensis & $22-35$ & 1 & 0.68 & 1 \\
\hline Microtus pennsylvanicus & $15-40$ & 2 & $0.52, \quad 0.64$ & 1 \\
\hline Spermophilus tridecemlineatus & $137-373$ & 5 & $0.20-0.41$ & 1 \\
\hline Rat & mature & 1 & 0.82 & 2 \\
\hline Rat & $180-430$ & 4 & $0.63-1.02$ & 3 \\
\hline Rat & $95-400$ & 5 & $0.62-0.94$ & 1 \\
\hline Guinea pig & mature & 1 & 0.80 & 2 \\
\hline Rabbit & mature & 1 & 0.79 & 2 \\
\hline Rabbit & $2.67-3.41 \mathrm{~kg}$ & 2 & $0.82, \quad 0.85$ & $\overline{3}$ \\
\hline Chicken & $2.15-2.85$ & 2 & $0.63,1.02$ & 3 \\
\hline Cat & mature & 1 & 0.90 & 2 \\
\hline Dog & $12-15$ & 4 & $0.52-0.80$ & 3 \\
\hline Sheep & mature & 1 & 0.88 & 2 \\
\hline Sheep & $32-46$ & 3 & $0.61-0.71$ & 3 \\
\hline Goat & mature & 1 & 0.95 & 2 \\
\hline Man & mature & 1 & 0.76 & 2 \\
\hline Man & $53-64$ & 4 & $0.33-0.42$ & 3 \\
\hline Cattle & $279-575$ & 10 & $0.33-4.96$ & 3 \\
\hline Horse & mature & 1 & 0.94 & 2 \\
\hline
\end{tabular}

1-Hart, 1971; 2-Blaxter, 1972; 3- Thonney et al., 1976.

range of changes in body weight and the metabolic rate do these exponents really show the degree of proportionality.

The search of literature for data revealed that only a few authors have studied the $B M R$ alterations during the life span of animals, and most only during a particular period of development. The existing data, although scarce, show that the intraspecific relation between body size and $B M R$ even on a log. log. plot is not represented by a straight line, as was pointed out by B r od y (1945). This is well illustrated by Fig. 2 redrawn from the paper by $\mathrm{Pi}$ e k a $\mathrm{r}$ e w s k a (1977). This illustration shows that the relation between the changes in $B M R$ of rabbits and the changes of their body weight from about $70 \mathrm{~g}$ to $2 \mathrm{~kg}$ is represented on a log. log. plot by a curve which the author divided into two 
straight sections. The slope of the first section is represented by the exponent $b=1.532$ whereas of the second one by $b=0.712$, for addition, there are some data on metabolic rates in rabbits weighing from 2 to $5 \mathrm{~kg}$, which are situated below the line of the second section. Analysing Fig. 2 one can easily imagine that if the author was studying the changes of $B M R$ in rabbits accompanying the changes of body weight from approximately 100 to $300 \mathrm{~g}$, then she would certainly feel justified to draw the line with a slope represented by $b \approx 1$. Similarly it would be possible to draw the line over the range of body weights

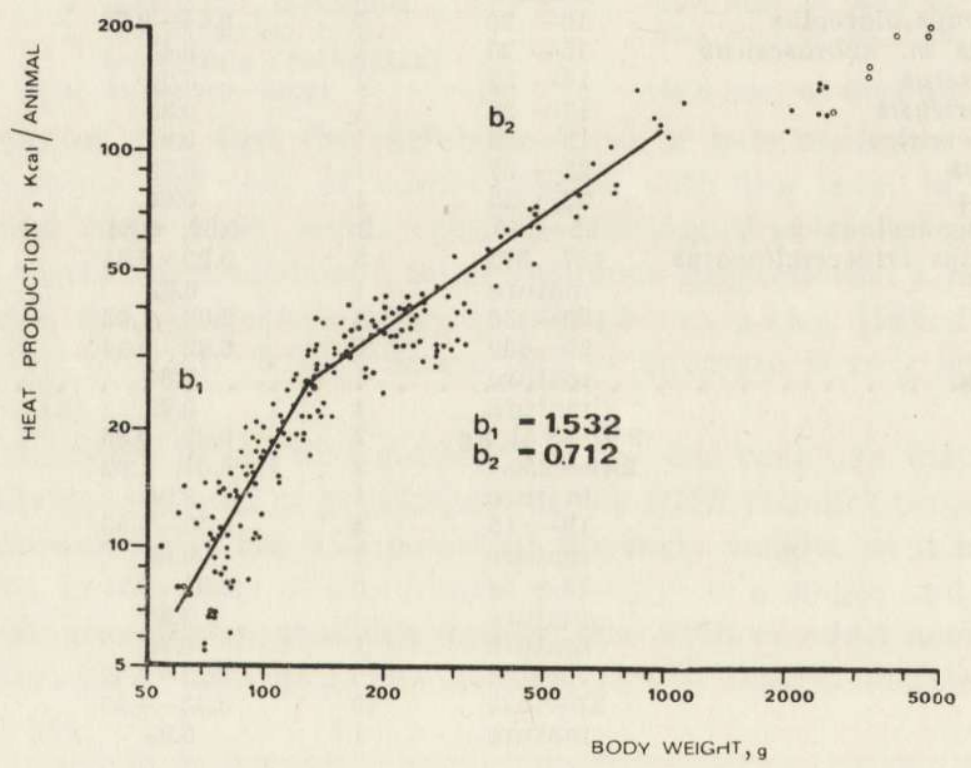

Fig. 2. Relationship between body size and the metabolic rate (expressed on a log. log. plot) in rabbits from birth to maturity. From Piekarzewska, 1977.

from $500 \mathrm{~g}$ to $5 \mathrm{~kg}$ and to calculate the $b$ value which would be approximately 0.6 . This explains why so many values of $b$ are reported even for the same animal species (see Table 2) and shows that these values in reality are useless.

A curvilinear relationship between the logarithms of body weight and logarithms of the metabolic rate in the chicken has been described by $\mathrm{Freeman}$ (1964). The author studied changes in the metabolic rates of 4 breeds of chicken during the first 2 weeks of their postembryonic life (from approximately 30 to $100 \mathrm{~g}$. body weight). In each breed he distinguished 2 phases of metabolism. In the first phase the 
regression coefficients (i.e. exponents b) were from 1.663 to 2.091 and in the second phase 0.761 to 1.038 . If Freeman had studied further changes in the metabolic rate in the chicken he would certainly have found the third phases. Two phases of the metabolism were also reported by Freeman (1967) for Japanese quail with regression coefficients 2.473 and 0.785 . Three metabolic phases has been described in developing Norwegian lemmings and golden hamsters ( $\mathrm{H}$ is s a, 1968). It seems therefore, that multiphasic changes of the metabolic rate in developing animals is a common phenomenon. The only exception found so far is the guinea pig in which the metabolic rate changes throughout postanatal development proportionally to 0.843 power of the body weight (P i e k a rzew ska, 1977).

When the metabolic rate of developing homeotherms are expressed per metabolic unit of the body weight i.e. $\mathrm{kg}^{0.75}$ it appears that the level of metabolism in new born specimens is approximately the same as in adult ones then increases to reach at a certain stage of development approximately double that level, and then gradually decreases. This is shown in Table 3 consisting of the data on the metabolic rates in 6 species of mammals and 3 species of birds. Similar alterations of the metabolic rates may be seen after recalculation of available data for growing horses (B rody et al., 1943), ducks (K o trbáč e k, 1973), and chicken ( $\mathrm{J}$ a s trzę b ski et al., 1977).

The rate of increase of the metabolic level seems to depend on the degree of maturity of an animal at its birth. This is illustrated by the Fig. 3 in which the metabolic rates of rats and chicken are plotted against their relative growth i.e. multiple of the average body weight at birth or hatch. It is evident that the higest metabolic level in the precocial chicken is at the time when its body weight is approximately 5 times that at hatch whereas in the "altricial « rat, only after a 15 fold increase of its body weight at birth.

\section{DISCUSSION AND CONCLUSIONS}

The evidence in this paper shows that the relationship between the changes of $B M R$ and body weight in ontogeny of homeotherms even on a log. log. plot is not represented by a straight line. For this reason the calculations of power equations, usually based on data concerning only a part of the animal's life span lead to quite different values of the exponent $b$. Most of the published exponents are therefore ill-defined and as such useless for prediction of the metabolic rates in animals at particular stages of their development. One can conclude therefore, 
that the analysis of intraspecific relations between $B M R$ and body weight with the help of the known power equation (see eq. 2) should be discarded as not giving clear and easily comparable results.

Table 3

Alterations of the body weight and $B M R$ during postnatal development of animals.

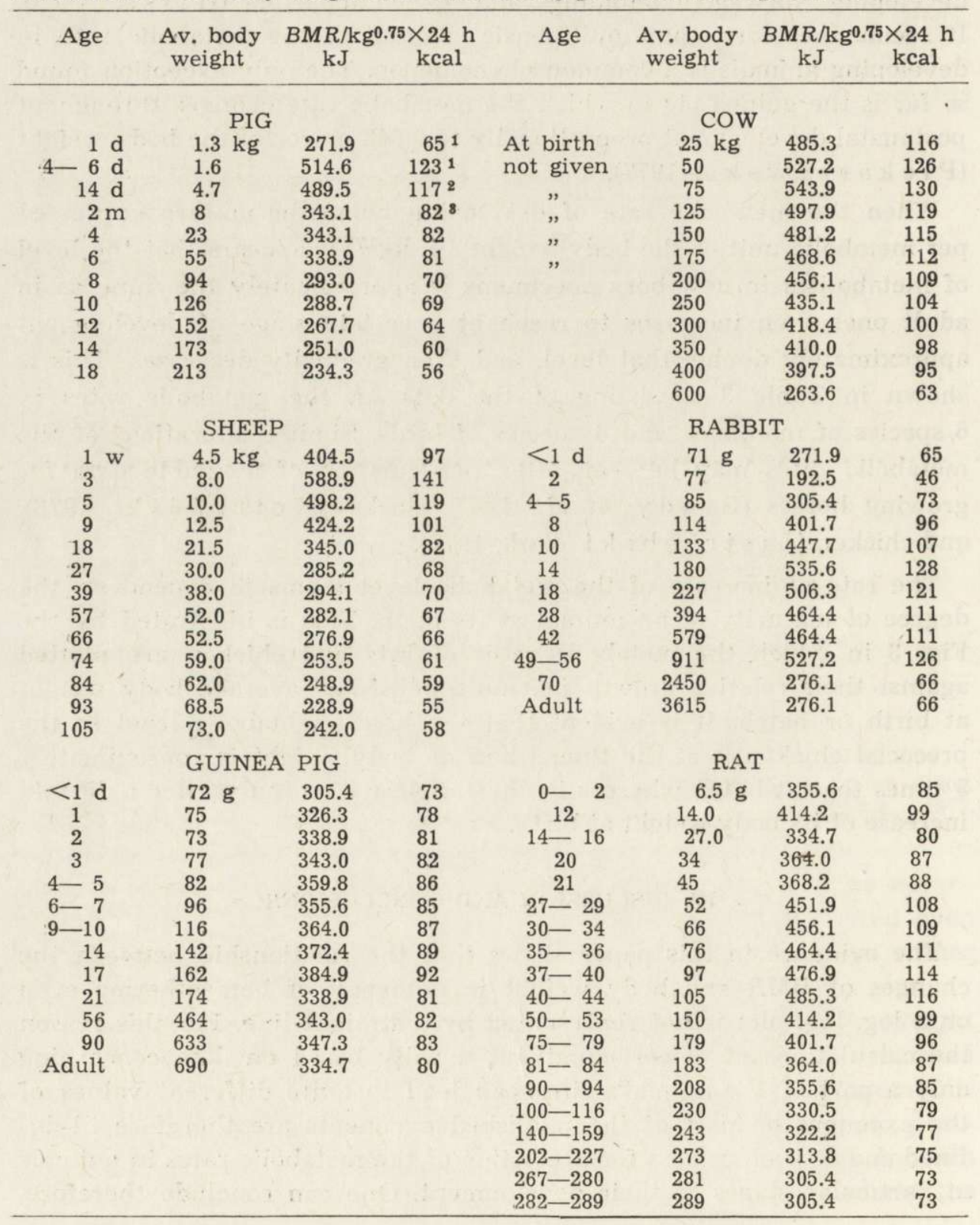




\section{CHICKEN}

\begin{tabular}{|c|c|c|c|}
\hline & $<7 d$ & 43 & 389.1 \\
\hline $7-$ & 14 & 54 & 485.3 \\
\hline $14-$ & 21 & 91 & 514.6 \\
\hline $21-$ & 28 & 152 & 577.4 \\
\hline $28-$ & 35 & 216 & 577.4 \\
\hline $35-$ & 42 & 299 & 472.8 \\
\hline $42-$ & 49 & 355 & 405.8 \\
\hline $49-$ & 60 & 39.2 & 393.3 \\
\hline $60-$ & 90 & 631 & 351.4 \\
\hline $90-$ & 120 & 1048 & 334.7 \\
\hline $120-$ & 150 & 1479 & 351.4 \\
\hline $150-$ & 180 & 1319 & 372.4 \\
\hline 180 & 210 & 1679 & 355.6 \\
\hline $210-$ & 240 & 1820 & 284.5 \\
\hline 240 & 270 & 1864 & 292.9 \\
\hline $270-$ & 300 & 1944 & 334.7 \\
\hline $300-$ & 330 & 1818 & 263.6 \\
\hline $330-$ & 360 & 1835 & 376.6 \\
\hline $1360-1$ & 1390 & 2084 & 271.9 \\
\hline
\end{tabular}

GOOSE

$\begin{array}{rrr}120 \text { g } & 242.7 & 58 \\ 480 & 376.6 & 90 \\ 670 & 589.9 & 141 \\ 2140 & 548.1 & 131 \\ 4000 & 506.3 & 121 \\ 4600 & 376.6 & 90 \\ 5200 & 364.0 & 87\end{array}$

\section{JAPANESE QUAIL}

$\begin{array}{rrrr}1 \mathrm{~d} & 6.5 \mathrm{~g} & 326.3 & 78 \\ 7 & 20 & 686.2 & 164 \\ 14 & 48 & 782.4 & 187 \\ 21 & 76 & 790.8 & 189 \\ 28 & 104 & 744.7 & 178 \\ 35 & 130 & 711.3 & 170 \\ 42 & 160 & 707.1 & 169\end{array}$

Explanations: Age of animals, $\mathrm{d}$ - days, $\mathrm{w}-$ weeks, $\mathrm{m}-$ months. Sources of data: pig ${ }^{1} \mathrm{M}$ ount \& Stephens, $1970 ;{ }^{2}$ Mount \& Rowell, $1960 ;{ }^{8} \mathrm{Brody}$ 1945; Cow - Brody, 1945; Sheep - Graham et al., 1974; Guinea pig and rabbit - Piekarzewska, 1977; Rat - Kleiber et al., 1956; Chicken Brody, 1945; - Goose - Poczopko, 1969; Japanese quail — Freeman, 1967.

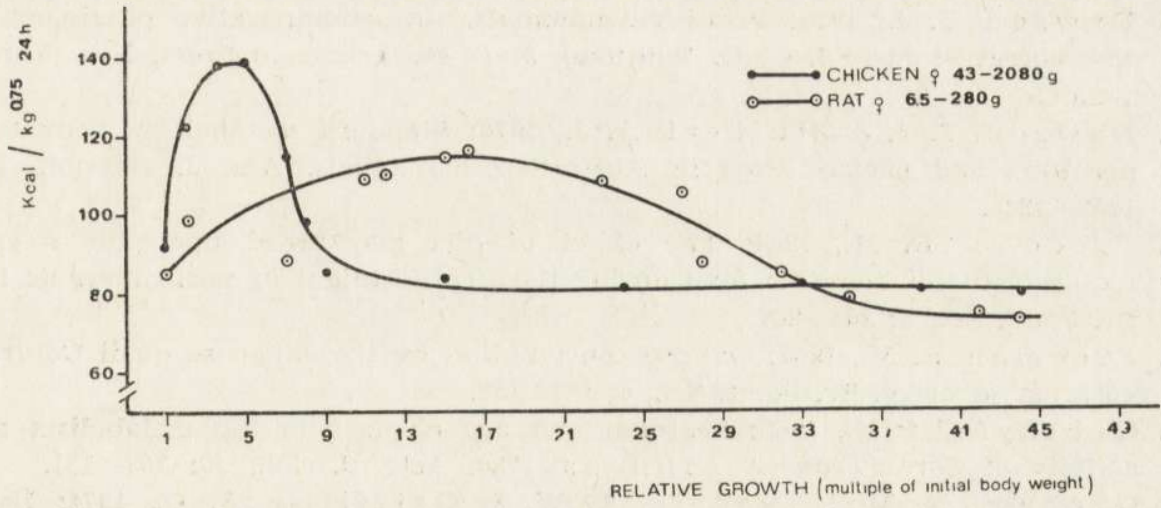

Fig. 3. Relationship between $B M R$ (expresšed per $\mathrm{kg} 0.75$ ) and relative growth (multiple of mean initial body wieght) in growing rats and chicken. Data on BMR in rats from Kleiber et al., 1956 and that in chicken from B rod y, 1945.

For comparative studies and for practical purposes the metabolic rates of growing animals can be expressed per common metabolic unit of body size i.e. $\mathrm{kg}^{0.75}$, just as has been done in Table 3 and Fig. 3. Such a presentation of the data demonstrate that at certain stage of development of animals their metabolic rate is twice as high as in the adult and new born specimens. Similarly we can tell that the metabolic rate of the new born pig is low whereas that of new born calf is high.

Clinical and animal husbandry men prefered long ago to use tables 
of energy metabolism of growing man and animals, in order to assess thyroid activity or nutrient requirements, rather than base these assessments on predicted values. It appears that this approach should be used also in comparative physiology.

Acknowledgement: I wish to express my sincere thanks to Professor G. Edgar Folk, Jr. for reading the manuscript and his comments.

\section{REFERENCES}

1. B la $\mathrm{xt}$ e r K. L., 1972: Fasting metabolism and the energy required by animals for maintenance. [In: »Festkrift til Professor Dr. Agr. Dr h.c. Knut Breirem «: 19-36]. Mariendals Boktrykkeri, A. s. Gjovik.

2. Brody S., 1945: Bioenergetics and growth. Reinhold: 1-1023, New York.

3. Brody S., Kibler H. H. \& Trowbridge E. A., 1943: Growth and development. 58. Resting energy metabolism and pulmonary ventilation in growing horses. Mo. Agr. Exp. Sta. Res. Bul., 368: 1-14.

4. Brody S. \& Proctor R. C., 1932: Growth and development with special references to domestic animals. 23. Relation between basal metabolism and mature body weight in different species of mammals and birds. M. Agr. Exp. Sta. Res. Bul., 166: 89-101.

5. Daws on T. J., 1973: Primitive mammals. [In: "Comparative physiology of thermoregulation" Ed. G. C. Whittow], 3: 1-46. Academic Press, New YorkLondon.

6. Dawson T. J. \& Hulbert A. J., 1970: Standard metabolism, body temperature, and surface area in Australian marsupials. Am. J. Physiol., 218: $1233-1238$.

7. Freeman B. M., 1964: The effect of diet and breed upon the oxygen requirements of domestic fowl during the first fortnight of postembryonic life. Br. Poult. Sci., 5: 263-267.

8. Freeman B. M., 1967: Oxygen consumption by the Japanese quail Coturnix coturnix japonica. Br. Poult. Sci., 8: 147-152.

9. Gębczyński M., 1965: Seasonal and age changes in the metabolism and activity of Sorex araneus Linneus 1758. Acta theriol., 10: 103-131.

10. Graham N. McC., Searle T. W. \& Griffiths A. D., 1974: Basal metabolic rate in lambs and young sheep. Aust. J. Agric. Res., 25: 957-971.

11. Hart J. S., 1971: Rodents. [In: „Comparative physiology of thermoregulation" Ed. G. C. Whittow], 2: 1-149. Academic Press, New York-London.

12. Hemmingsen A., 1960: Energy metabolism as related to body size and respiratory surface and its evolution. Rep. Steno. Hosp. Nord. Insulinlab., 9: $1-110$.

13. H is S a R., 1968: Postnatal development of thermoregulation in Norwegian lemming and golden hamster. Ann. Zool. Fenn., 5: 345-385.

14. Jastrzębski M. \& Pietras M., 1977: Aktywność tarczycy i przemiana podstawowa u kurcząt rasy white rock w okresie wzrostu. Rocz. nauk zoot. 4: $55-62$.

15. King J. R. \& F a rne r D. S., 1961: Energy metabolism, thermoregulation and body temperature. [In: "Biology and comparative physiology of birds", Ed. A. Marshall] 2: 215-288, Academic Press, New York-London. 
16. Kleiber M., 1932: Body size and metabolism. Hilgardia, 6: 315-353.

17. Kleiber M., 1947: Body size and metabolic rate. Physiol. Rev., 27: 511-541.

18. Kleiber M., 1961: The fire of life. J. Wiley \& Sons: 1-454, New YorkLondon.

19. Kleiber M., 1965: Metabolic body size. [In: "Energy metabolism", Ed. K. L. Blaxter]: 427-435. Academic Press, London- New York.

20. Kleiber M., Smith A. H. \& Chernikoff T. N., 1965: Metabolic rate of female rats as a function of age and body size. Am. J. Physiol., 186: $9-12$.

21. Kotrbáček V., 1973: Age dependent changes in $\mathrm{O}_{2}$ consumption and $\mathrm{CO}_{2}$ production of Pekin ducks from hatch to 60 days of age at different ambient temperatures. Acta vet. Brno, 42: 15-21.

22. $\mathrm{Krogh}$ A., 1916: The respiratory exchange in animals and man. Longmans Green, London.

23. Lasiewski R. C. \& Dawson W. R., 1967: A re-examination of the relation between standard metabolic rate and body weight in birds. Condor, 69: $13-23$.

24. M e e h K., 1879: Oberfläschenmessungen des menschlichen Körpers. Z. Biol., 15: $425-428$.

25. Mount L. E. \& Rowell J. G., 1960: Body weight and age in relation to the metabolic rate of the young pig. Nature, Lond. 186: 1054-1055.

26. Mount L. E. \& Stephens D. B., 1970: The relation between body size and maximum and minimum metabolic rates in new-born pigs. J. Physiol., 207: $417-427$.

27. Piekarzewska A. B., 1977: Changes in thermogenesis and its hormonal regulators during postnatal development of rabbits and guinea pigs. Acta theriol., 22: 159-180.

28. Poczopko P., 1965: Contribution to the studies on changes of energy metabolism during postnatal development. II. Changes of surface to weight ratio in developing rats. Acta physiol. pol., 16: 752-756.

29. Poczopko P., 1969: Effect of fasting time on respiratory quotient and metabolic rate in gees of different age. [In: "Energy metabolism of farm animals ", Ed. K. L. Blaxter, J. Kielanowski \& G. Thorbek]: 361-367, Oriel Press Ltd., Newcastle.

30. Poczopko P., 1971: Metabolic levels in adult homeotherms. Acta theriol., 16: $1-21$.

31. R u bner M., 1883: Über den Einfluss der Körpergrosse auf Stoff-und Kraft-wechsel. Z. Biol., 19: 535-562.

32. Thonney M. L., Touchberry R. W., Goodrich R. D., \& Meiske J. C., 1976: Intraspecies relation between fasting heat production and body weight: a reevaluation of $W^{0.75}$. J. Anim. Sci., 43: 692-704.

33. Vogel P., 1976: Energy consumption in European and African shrews. Acta theriol. 21: 195-206.

34. Voit E., 1901: Über die Grösse der Energiebedarfs der Tiere in Hungerzustande. Z. Biol., 41: 113-154.

Accepted, October 20, 1978. 


\section{Piotr POCZOPKO}

\section{ZALEŻNOSC MIĘDZY TEMPEM METABOLIZMU A ROZMIARAMI CIAŁA DOROSEYCH I ROSNĄCYCH ZWIERZATT STAEOCIEPLNYCH}

\section{Streszczenie}

Zależność między tempem przemiany podstawowej $(B M R)$ a rozmiarami ciała dorosłych zwierząt stałocieplnych na układzie współrzędnych o skali podwójnie logarytmicznej ilustruje linia prosta. Zależność tę można zatem opisać równaniem $M=a W b$, gdzie $M=B M R, W=$ ciężar ciała $\mathrm{w} \mathrm{kg}$, a $a$ i $b$ są stałymi. Wykładnik potęgowy $b$ obliczony przez wielu autorów dla licznych grup dorosłych zwierząt nie różnił się istotnie od wartości 0.75 , zatem ciężar ciała w kilogramach podniesiony do tej potęgi (kg0.75) można przyjąć za ogólną metaboliczną jednostkę rozmiarów ciała dorosłych zwierząt. Gdy dostępne w literaturze dane o BMR przeliczy się na tę jednostkę da się wyróżnić szereg poziomów metabolizmu charakterystycznych dla różnych grup zwierząt. U rosnących zwierząt stałocieplnych zależność między $B M R$ a ciężarem ciała nawet na układzie współrzędnych o ska!: podwójnie logarytmicznej nie jest reprezentowana przez linię prostą. Zatem zależności tej nie można charakteryzować jednym tylko współczynnikiem regresji. Wnioskuje się więc, aby $w$ analizie wewnątrzgatunkowej zależności między $B M R$ i ciężarem ciała zaniechać posługiwania się równaniem $M=a W b$, ponieważ nie prowadzi ono do łatwo porównywalnych wyników. W badaniach porównawczych można wyrażać tempo metabolizmu rosnących zwierząt w przeliczeniu na ogólną metaboliczną jednostkę rozmiarów ciała, tj. kg0.75. Takie podejście umożliwia bowiem porównywanie tempa metabolizmu zarówno zwierząt należących do różnych gatunków, jak i różniących się ciężarem ciała osobników tego samego gatunku. 